\title{
HAMBATAN DALAM PENYELESAIAN SENGKETA KASUS MINYAK MONTARA
}

\author{
Ni Putu Suci Meinarni \\ STIKI INDONESIA \\ Jalan Tukad Pakerisan No. 97 Denpasar \\ Email : sucimeinarni@gmail.com
}

\begin{abstract}
ABSTRAK
Pemerintah Indonesia tidak dapat memaksakan ketaatan PTTEP Australasia untuk membayar ganti rugi kepada Pemerintah Indonesia. Sebab, berdasarkan hasil penelitian yang melibatkan berbagai perguruan tinggi di Australia, dampak dari ledakan minyak Montara sama sekali tidak signifikan dan aman bagi seluruh flora dan fauna yang ada disekitar wilayah laut terjadinya ledakan minyak. Hambatan dalam penyelesaian Kasus Minyak Montara, antara lain : belum adanya aturan hukum internasional yang khusus mengatur pencemaran akibat kegiatan eksploitasi minyak lepas pantai, kurangnya koordinasi antara Pemerintah Pusat dan Pemerintah Daerah, perusahaan pengeboran minyak lepas pantai PTTEP Australasia merupakan perusahaan berbendera Thailand yang beroperasi di wilayah Australia, pihak PTTEP menyatakan bahwa Ledakan Minyak Montara tidak berdampak terhadap Indonesia.
\end{abstract}

Kata kunci : Penyelesaian Sengketa, Kasus Minyak Montara, Pencemaran

\begin{abstract}
The Indonesian government can not force obedience PTTEP Australasia to pay compensation to the Government of Indonesia. Therefore, based on the results of studies involving various universities in Australia, the impact of the explosion of the Montara oil altogether insignificant and safe for the entire flora and fauna that exist around the sea area of the explosion of oil. Obstacles in solving cases Montara Oil, among others: the absence of the rule of international law that specifically regulates pollution caused by oil exploitation activities offshore, lack of coordination between the central government and regional governments, companies drilling offshore oil PTTEP Australasia is a company flagged Thailand operating in the region Australia, the PTTEP stated that the explosion of Montara Oil had no impact on Indonesia.
\end{abstract}

Keywords: Settlement, Case Montara Oil, Pollution

\section{Pendahuluan}

Dalam pembahasan tentang aturan internasional dan legislasi nasional untuk mencegah, mengurangi, dan mengendalikan pencemaran lingkungan laut, Pasal 207-212 UNCLOS 1982 menyebutkan secara khusus enam jenis pencemaran laut, yaitu: pencemaran dari sumber daratan, pencemaran dari aktivitas dasar laut yang termasuk dalam yurisdiksi nasional, pencemaran dari aktivitas dalam area terkait, pencemaran oleh dumping, pencemaran dari kapal, dan pencemaran dari atau melalui atmosfer. 
UNCLOS 1982, Pasal 192, menyatakan bahwa seluruh negara diwajibkan untuk melindungi dan melestarikan lingkungan laut. Kewajiban ini seimbang dengan hak yang diberikan kepada setiap negara untuk mengeksploitasi kekayaan alamnya, sesuai dengan kebijaksanaan lingkungan dari masing-masing negara. Artinya, setiap negara memiliki kebebasan untuk mengeksplorasi dan mengeksploitasi kekayaan alamnya, termasuk di dalamnya lingkungan laut, yang disertai dengan tanggung jawab untuk menjaga kelestarian lingkungan atau kekayaan yang dieksploitasi.

Faktanya, banyak negara yang melakukan eksploitasi berlebih, tanpa memperhatikan kelestarian laut dan sumber daya yang ada di dalamnya. Ditambah lagi, tindakan-tindakan pelestarian dan perlindungan lingkungan laut seringkali diabaikan dan tidak dilaksanakan secara optimal. Tindakan-tindakan semacam ini tidak hanya merugikan negara terkait, melainkan juga negara lain yang terletak di sekitar negara terkait. Lebih lanjut lagi, kondisi tersebut memicu terjadinya sengketa antara negara atau pihak yang disinyalir sebagai penyebab kerusakan atau pencemaran dengan negara atau pihak lain yang terkena imbas kerusakan atau pencemaran tersebut.

UNCLOS 1982, Pasal 192, menyatakan bahwa seluruh negara diwajibkan untuk melindungi dan melestarikan lingkungan laut. Kewajiban ini seimbang dengan hak yang diberikan kepada setiap negara untuk mengeksploitasi kekayaan alamnya, sesuai dengan kebijaksanaan lingkungan dari masing-masing negara. Artinya, setiap negara memiliki kebebasan untuk mengeksplorasi dan mengeksploitasi kekayaan alamnya, termasuk di dalamnya lingkungan laut, yang disertai dengan tanggung jawab untuk menjaga kelestarian lingkungan atau kekayaan yang dieksploitasi.

Faktanya, banyak negara yang melakukan eksploitasi berlebih, tanpa memperhatikan kelestarian laut dan sumber daya yang ada di dalamnya. Ditambah lagi, tindakan-tindakan pelestarian dan perlindungan lingkungan laut seringkali diabaikan dan tidak dilaksanakan secara optimal. Tindakan-tindakan semacam ini tidak hanya merugikan negara terkait, melainkan juga negara lain yang terletak di sekitar negara terkait. Lebih lanjut lagi, kondisi tersebut memicu terjadinya sengketa antara negara atau pihak yang disinyalir sebagai penyebab kerusakan atau pencemaran dengan negara atau pihak lain yang terkena imbas kerusakan atau pencemaran tersebut.

Pada tahun 2009, Indonesia mengalami kasus pencemaran lingkungan laut, yang pada akhirnya berujung pada sengketa dengan pihak swasta yang terkait dengan pencemaran tersebut. Tanggal 20 Agustus 2009, telah terjadi ledakan di ladang minyak Montara yang berada di kawasan Zona Ekonomi Ekslusif (ZEE) Australia. Ledakan tersebut mengakibatkan tumpahnya minyak mentah yang meluas sampai kepada wilayah ZEE Indonesia.

Ledakan ladang minyak Montara menjadi kasus luapan minyak terbesar yang terjadi di ladang minyak Montara di Laut Timor, yang terletak di pantai utara 
Australia. Ladang minyak Montara terletak di pantai Kimberley, $250 \mathrm{~km}$ di utara Truscott, dan $690 \mathrm{~km}$ di barat Darwin. Kasus ini merupakan salah satu bencana minyak terbesar yang dialami Australia. Aliran minyak terjadi sejak 21 Agustus 2009 dan berlanjut hingga 3 November 2009. Kedutaan Besar Australia di Jakarta menjelaskan bahwa minyak mentah mulai mengalir menuju Laut Timor pada tanggal 21 Agustus 2009, dan memberikan notifikasi kepada Pemerintah Indonesia setelah diperoleh citra satelit pada tanggal 1 September 2009 yang menunjukkan bahwa tumpahan minyak mengalir menuju ZEE Indonesia dalam bentuk gumpalan. Sebagai langkah lanjutan, pada tanggal 28 Oktober 2009, the Minister for the Environment, Heritage and the Arts, Peter Garrett, menjelaskan secara langsung kepada Menteri Lingkungan Indonesia, Gusti Muhammad Hatta, terkait dengan permasalahan tumpahan minyak Montara.

Kerugian ditimbulkan oleh tumpahan minyak mencemari kawasan laut Indonesia, Australia, dan Timor Leste. Negara Republik Indonesia cukup besar. Pemerintah Indonesia bersama-sama dengan Australia bertanggungjawab dalam memelihara dan memberikan perlindungan terhadap lingkungan. Salah satu langkah yang ditempuh untuk dapat menyelesaikan kasus pencemaran minyak ini, Pemerintah Indonesia mengajukan perkara pencemaran laut tersebut ke dalam sengketa dengan PTTEP Australasia

Berdasarkan latar belakang diatas, maka penulis tertarik untuk memaparkan mengenai "Hambatan dalam Penyelesaian Sengketa Kasus Pencemaran Minyak Montara di Laut
Timor antara Pemerintah Republik Indonesia dan Australia".

\section{Pembahasan \\ Hambatan Dalam Penyelesaian Sengketa Kasus Platform Montara Setiap proses dalam} penyelesaian sengketa antar negara tentunya memiliki hambatannya masing-masing. Hal ini disebabkan oleh perbedaan sudut pandang dan kepentingan dari masing-masing pihak. Tentunya para pihak akan membela dan mempertahankan kepentingannya. Sehingga sering kali penyelesaian suatu sengketa memerlukan waktu yang cukup panjang.

Permasalahan dalam penyelesaian sengketa Kasus Minyak Montara ini pada dasarnya, adalah ketidaksepakatan antara Pemeritah Republik Indonesia dengan PTTEP Australasia mengenai klaim ganti kerugian yang harus dibayarkan oleh PTTEP Australasia. Selain ketidaksepakatan antara Indonesia dan PTTETP, kendala-kendala lain dalam penyelesaian sengketa pencemaran minyak oleh PTTEP Australasia yang cukup rumit. Beberapa hambatan-hambatan tersebut antara lain :

\section{Belum adanya aturan hukum internasional yang khusus mengatur pencemaran akibat kegiatan eksploitasi minyak lepas pantai.}

Kondisi ini menyebabkan pemerintah indonesia kesulitan dalam menentukan penyelesaian permasalahan-permasalahan yang timbul akibat hal tersebut (Rayyanul M. Sangadji). Pencemaran minyak akibat pengeboran minyak lepas pantai merupakan hal yang belum 
diatur secara khusus dalam pencemaran laut, sebagaimana rezim pencemaran lingkungan laut yang diakui dalam UNCLOS 1982.

Pasal 207-212 UNCLOS 1982 mengatur mengenai pencemaran lingkungan yang bersumber dari dumping, pencemaran laut sumber darat, pencemaran laut yang bersumber dari kegiata-kegiatan dari laut yang tunduk pada yurisdiksi nasional, pencemaran yang berasal dari kegiatan-kegiatan di kawasan, pencemaran yang berasal dari kendaraan air dan pencemaran yang berasal dari atau melalui udara. Dengan demikian, dapat diketahui secara nyata bahwa pencemaran lingkungan akibat pengeboran minyak lepas pantai merupakan hal yang baru.

Sejauh ini, aturan internasional mengenai pencemaran akibat minyak yang bersumber dari kapal telah diatur dalam International Convention for the Prevention of Pollution from Ships 1973/1978 (MARPOL 1973/1978). MARPOL adalah peraturan-peraturan internasional yang bertujuan untuk mencegah terjadinya pencemaran di laut. Isi dalam MARPOL bukan melarang pembuangan zat-zat pencemar ke laut, tetapi mengatur cara pembuangannya. Agar dengan pembuangan tersebut laut tidak tercemar (rusak), dan ekosistim laut tetap terjaga.

Selain MARPOL, aturan hukum internasional lainnya yang berkaitan dengan polusi yang terjadi di laut ialah Civil Liability Convention 1992 (CLC 1992 yang menggantikan CLC 1969), mengenai kompensasi ganti kerugian atas pencemaran minyak di laut dan Fund Convention 1992 (menggantikan Fund Convention
1971), yang merupakan konvensi tambahan bagi CLC 1992 yang diperuntukkan bagi korban selaku penerima kompensasi atau ganti rugi (Mark Jacobson, 2007).

CLC 1992 mengatur mengenai kewajiban pemilik kapal akan bahaya dari minyak, dimana konvensi ini menetapkan kepada para pemilik kapal akan tanggung jawab mutlak dan kewajiban untuk mengasuransikan usahanya. Konvensi ini dibentuk untuk pencemaran minyak yang dihasilkan oleh tumpahan minyak dari kapal atau tanker. Didalam konvensi ini, International Maritime Organization (IMO), sebagai organisasi maritim internasional memiliki ruang lingkup untuk membantu para anggotanya untuk mendapatkan kompensasi. CLC 1992 dalam penetapan jumlah ganti rugi memiliki batasan-batasan, dihitung dari jumlah yang terangkut (dalam satuan ton) (IOPC Funds, 2012).

Pada prinsipnya pemberian kompensasi yang diatur dalam CLC adalah pencermaran akibat minyak yang berasal dari aktivitas kapal, baik pengangkutan maupun hasil limbah transportasi kapal. Dan pemberian ganti rugi pada CLC bersifat terbatas (masih dapat dihitung) berbanding dengan muatan pada kapal pengangkut minyak. Sehingga dapat diasumsikan bahwa CLC tidak dapat digunakan sebagai dasar penyelesaian sengketa tumpahan minyak di laut dari pengeboran lepas pantai. Penyebab terjadinya pencemaran adalah berbeda, dan volume tumpahan juga berbeda. Volume tumpahan minyak akibat eksplorasi lepas pantai tidak terhitung jumlahnya (unlimited) selama kebocoran masih belum 
ditanggulangi, jadi sudah dapat dipastikan kerugian yang terjadi akan jauh lebih besar. Dan berarti, pasalpasal dalam CLC 1992 dan Fund Convention 1992 hanya dapat dijadikan sebagai pembanding (sebatas rekomendasi).

Dikarenakan tidak ada aturan hukum internasional mengenai hal tersebut, menyebabkan sulitnya pula pemerintah untuk menentukan aparatur atau lembaga pemerintahan mana yang akan menyelesaikan sengketa tersebut, sehingga pemerintah membentuk satu tim khusus yang terdiri atas beberapa instansi pemerintah terkait. Tim Nasional Penanggulangan Keadaan Darurat Pencemaran Minyak, yang diketuai oleh Menteri Perhubungan sesuai dengan Peraturan Presiden Nomor 109 tahun 2006.

Pada tahun 2009, Pemerintah membentuk Tim Terpadu Observasi Tumpahan Minyak di Laut Timor Perairan Indonesia, dimana dalam laporan observasinya tim terpadu merekomendasikan salah satunya adalah mengenai perlunya pemahaman dasar hukum internasional terkait klaim ganti rugi tumpahan minyak yang bersumber dari rig. Dengan demikian, pemerintah secara sadar bahwa tidak ada hukum interanasional yang mengatur mengenai hal tersebut. Jika ada aturan hukum interasional mengenai hal tersebut maka akan lebih mudah untuk menentukan dasar-dasar penentuan kerugian yang dibuat. Mengingat, besarnya tuntutan ganti kerugian pemerintah daerah Provinsi Nusa Tenggara Timur terhadap pencemaran minyak akibat ledakan ladang minyak Montara.

Berdasarkan hasil observasi Tim Terpadu, bahwa secara kasat mata tidak ditemukan pencemaran akibat ledakan ladang minyak Montara di wilayah laut Indonesia. Beberapa hasil observasi visual tim terpadu antara lain, terlihat adanya lapisan berwarna coklat muda pada permukaan air laut dan butiranbutiran/emulsi pada air laut, permukaan air laut pada kondisi normal, di permukaan air lau terlihat kelompok lumba-lumba, terlihat burung camar bermain di permukaan air laut. Selain itu, dengan melakukan pemancingan dari kapal survei diperoleh Ikan Kakap Merah, Ikan Kerapu Macan, Ikan Kerapu Merah dan Ikan Kakatua, kondisi visual seluruh ikan pada insang normal.

\section{Kurangnya koordinasi antara Pemerintah Pusat dan Pemerintah Daerah.}

Kurangnya koordinasi antara Pemerintah Pusat dan Pemerintah Daerah menyebabkan penyusunan klaim atas kasus pencemaran minyak ini menjadi tidak akurat (Rusmana Rusmana).

Ketidak-akuratan data dan hasil penelitian terhadap kasus pencemaran minyak montara dan akibatnya terhadap wilayah perairan Indonesia, kurang dapat menjadi dasar perhitungan ganti kerugianyang dapat diterima oleh seluruh pihak. Perlu sinergi antara pemerintah dan masyarakat untuk memperkuat upaya penyelesaian kasus tumpahan minyak dari sumur Montara (Kompas, 15 Agustus 2012).

Perusahaan pengeboran minyak
$\begin{aligned} & \text { lepas pantai } \\ & \text { merupakan }\end{aligned}$ PTTEP Australasia
$\begin{aligned} & \text { berbendera perusahaan } \\ & \text { beroperasi di wilayah Australia. }\end{aligned}$

Perusahaan pengeboran minyak lepas pantai PTTEP Australasia merupakan perusahaan berbendera Thailand yang beroperasi di wilayah Australia. 
Berdasarkan wawancara penulis dengan salah satu staf Kementerian Luar Negeri Republik Indonesia bahwa pihak Indonesia telah melakukan survei atau kunjungan ke PTTEP Australasia di Thailand. Dari survei tersebut, diketahui bahwa perusahaan tersebut bukanlah perusahaan yang besar, dan pihak Kementrian Luar Negeri pesimis jika nantinya PTTEP Australasia akan mampu memberikan ganti rugi sesuai angka yang tertera pada klaim ganti rugi (Rayyanul $M$. Sangadji).

\section{Pihak PTTEP menyatakan bahwa Ledakan Minyak Montara tidak berdampak terhadap Indonesia.}

Asumsi PTTEP Australasia mengenai dampak Kasus Minyak Montara terhadap Indonesia dikarenakan bahwa PTTEP Australasia menganggap perusahaan telah mampu mengendalikan pencemaran tersebut. PTTEP juga telah bergabung dengan Tim dibawah naungan Pemerintah Australia untuk melanjutkan pemantauan dan evaluasi efek tumpahan minyak dari ladang Montara dan menemukan bahwa daerah yang terkena pencemaran hanya terbatas pada wilayah sekitar ladang Montara.

Sebuah studi ilmiah yang dilakukan oleh suatu lembaga lingkungan independen Australia bagian barat menunjukkan bahwa tidak ada minyak mentah yang mencapai pantai barat Australia. PTTEP Australasia tidak menerima klaim kompensasi berkaitan dengan laporan dampak pencemaran di perairan Indonesia dari insiden di Laut Timor tahun lalu. Perusahaan tidak menerima bukti-bukti yang menguatkan bahwa terdapat hal-hal yang membahayakan lingkungan. Jika klaim diterima, bukti-bukti akan diperkirakan dan klaim akan dimasukkan ke dalam anggaran mereka. PTTEP sebelumnya telah mencoba melalui lembaga Pemerintah Australia terkait guna memberikan klarifikasi melalui media mengenai minyak mentah dari Montara yang masuk ke perairan Indonesia.

Selain melakukan kerjasama dengan lembaga-lembaga independen, PTTEP Australasia juga melakukan kerjasama dengan universitas-universitas di Australia untuk melakukan penelitian berkaitan dengan dampak ledakan minyak terhadap ekosistem dan lingkungan laut di sekitar wilayah ledakan minyak, bahkan sampai dengan wilayah perairan laut Indonesia.

Beberapa universitas yang melakukan kerjasama dalam bidang ini dengan PTTEP Australasia antara lain The University of Queensland, Curtin University, Charles Darwin University, Monash University. Kesimpulan dari hasil penelitian yang dilakukan oleh universitasuniversitas tersebut, bahwa dampak ledakan minyak montara dalam beberapa hal tidak begitu membahayakan. Hasil penelitian tersebut, antara lain (www.pttep.co.au) :

a) Aplikasi kimia dispersant disebabkan peningkatan dalam konsentrasi hidrokarbon dalam kolom air, sebagian besar berada dalam satu meter pertama kolom air.

b) Konsentrasi berkurang dengan cepat seiring dengan berjalannya waktu, kedalaman dan jarak dari dispersant. 
c) Tidak ada minyak yang mencapai daratan Australia atau pantai Indonesia.

d) Ledakan minyak terbesar terjadi di $22.8 \mathrm{~km}$ dari lokasi pelepasan.

e) $98,6 \%$ hidrokarbon terjadi di perairan Australia.

f) Populasi burung sehat.

g) Tidak ada dampak yang dapat diamati pada vegetasi.

h) Tidak ada tanda visual dari minyak atau lilin minyak di laut sekitar permukaan karang.

i) Tidak ada bukti gangguan yang menunjukkan efek minyak mencapai terumbu karang.

j) Beberapa pemutihan karang tampak jelas, kemungkinan disebabkan oleh stres termal wilayah yang luas.

k) Ekosistem berisi komunitas biologis yang beragam

1) Tidak ada tanda-tanda jelas gangguan terakhir

m)Meskipun ada indikasi paparan hidrokarbon minyak bumi, semua sampel ikan berada dalam kondisi yang baik dan menunjukkan status kesehatan yang baik.

n) Investigasi kemungkinan rembesan hidrokarbon alam.

o) Tidak ada kontaminasi minyak yang diamati sepanjang pantai.

p) Tampak keanekaragaman signifikan dan jumlah megafauna laut.

q) Temuan awal menunjukkan tidak ada hidrokarbon minyak bumi yang terdeteksi di dalam sampel otot ikan.

r) Sampel ikan aman untuk dimakan.

s) Meskipun indikasi paparan hidrokarbon minyak bumi, semua sampel ikan berada dalam kondisi yang baik, menunjukkan status kesehatan yang baik.
Hasil penelitian yang diperoleh oleh PTTEP Australasia inilah yang kemudian menjadi dasar PTTEP Australasia dalam melakukan pembayaran ganti kerugian. Maka tidak heran jika hingga saat ini, Pemerintah Indonesia tidak dapat memaksakan ketaatan PTTEP Australasia untuk membayar ganti rugi kepada Pemerintah Indonesia. Sebab, berdasarkan hasil penelitian yang melibatkan berbagai perguruan tinggi di Australia, dampak dari ledakan minyak Montara sama sekali tidak signifikan dan aman bagi seluruh flora dan fauna yang ada disekitar wilayah laut terjadinya ledakan minyak.

Di satu sisi, fakta bahwa hasil penelitian yang dilakukan oleh Pemerintah Indonesia bersama-sama dengan Pemerintah Daerah Nusa Tenggara Timur memiliki banyak kelemahan, tentunya menjadi kelemahan bagi Pemerintah Indonesia untuk dapat memaksakan PTTEP Australasia untuk melakukan berbagai tindakan pemulihan atas kerusakan-kerusakan lingkungan akibat ledakan minyak Montara yang diklaim oleh Pemerintah Indonesia.

Sebagai langkah penyelesaian mengenai perbedaan pendapat antara Pemerintah Indonesia dan PTTEP Australasia mengenai dampak ledakan minyak Montara terhadap laut dan lingkungan laut Indonesia, maka perlu dilakukan kerjasama (partnership) antara Pemerintah Indonesia dan PTTEP Australasia untuk melakukan penelitian yang komprehensif dan objektif. Dengan demikian, data yang diperoleh merupakan gambaran yang jelas atas kondisi yang terjadi, sehingga dapat diterima oleh kedua belah pihak. 


\section{Simpulan}

Hambatan dalam penyelesaian sengketa antar negara merupakan hal yang wajar terjadi. Demikian pula dengan penyelesaian Kasus Minyak Montara ini, beberapa hambatan yang penulis peroleh antara lain :

a. Belum adanya aturan hukum internasional yang khusus mengatur pencemaran akibat kegiatan eksploitasi minyak lepas pantai.

b. Kurangnya koordinasi antara Pemerintah Pusat dan Pemerintah Daerah.

c. Perusahaan pengeboran minyak lepas pantai PTTEP Australasia merupakan perusahaan berbendera Thailand yang beroperasi di wilayah Australia.

d. Pihak PTTEP menyatakan bahwa Ledakan Minyak Montara tidak berdampak terhadap Indonesia.

\section{Saran}

Sebaiknya diadakan kerjasama (partnership) antara Pemerintah Indonesia dan PTTEP Australasia untuk melakukan penelitian yang komprehensif dan objektif. Dengan demikian, data yang diperoleh merupakan gambaran yang jelas atas kondisi yang terjadi, sehingga dapat diterima oleh kedua belah pihak. Diharapkan penyelesaian sengketa Kasus Minyak Montara ini dapat tercapai sesegera mungkin.

\section{Daftra Pustaka}

Hasil wawancara dengan Erlina Luswiyati, Kasubdit Pencemaran Perairan. Ditjen Pengawasan dan Pengendalian Sumberdaya Kelautan dan Perikanan Kementrian Kelautan dan Perikanan. Jakarta.
Hasil wawancara dengan Rayyanul M. Sangadji.

Hasil wawancara dengan Rusmana Rusmana SH, MH, Kepala Biro Hukum Kementrian Kelautan dan Perikanan Republik Indonesia. Jakarta,

IOPC Funds, 2012, The International Regime for Compensation for Oil Pollution Damage, Explanatory Note, www.iopcfund.org. Diakses pada tanggal 11 Agustus 2012.

Jacobson, Mark, 2007, Uniform Application of the International Regime on Liability and Compensation for Oil Pollution Damage, Law of the Sea, Environmental law and Settlement of Disputes, Koninklijke Brill, Netherlands.

Kompas, 15 Agustus 2012, Kasus Montara Perlu Sinergi Pemerintah dan Masyarakat, Jakarta, hlm. 16.

Rekomendasi Tim Terpadu www.pttep.co.au, Post Montara Environmental Monitoring Update PTTEP Australasia. Diakses tanggal 07 Juni 2012. 